\title{
Formulation, Characterizations and Antibacterial Activity of some Nanoemulsions Incorporating Monoterpenes
}

Mona A. Abdelrasoul ${ }^{1}$; Asia R. E Ahmed ${ }^{2}$ and M. E. I. Badawy ${ }^{3}$

${ }^{1}$ Department Plant Protection, Faculty of Agriculture, Damanhour University, Damanhour Egypt.

${ }^{2}$ Department Plant Pathology, Faculty of Agriculture, Damanhour University, Damanhour Egypt.

${ }^{3}$ Department Pesticide Chemistry and Technology, Faculty of Agriculture, 21545 El-Shatby, Alexandria University, Alexandria, Egypt

\begin{abstract}
In the current study, we formulated and characterized bio-based oil in water nanoemulsions incorporating monoterpenes; $(R)$-carvone, cinnamaldehyde, citral, geraniol and pulegone and tested their antimicrobial activity against two plant pathogenic bacteria, Pectobacterium carotovorum sub carotovorum and Ralstonia solanacearum in vitro and in vivo studies. Nanoemulsions (NEs) were prepared by adding dropwise monoterpenes at concentration of $5 \%$ in an aqueous solution containing $10 \%$ a surfactant (tween 80) with constant stirring and then ultrasonication. NEs were confirmed by dynamic light scattering and transmission electron microscopy. Physical stability and viscosity were, also, investigated. NEs monoterpenes had a poly dispersity index ranged from 0.130 to 0.630 and droplet size in the range of 56.64-176.00 nm. Results revealed that NE cinnamaldehyde had great antibacterial activity against $P$. carotovorum and $R$. solanacearum (MIC $=60$ and $100 \mathrm{mg} / \mathrm{L}$, respectively). NE cinnamaldehyde was induced effective defense responses in vivo in potato plant and tubers against two tested bacteria at a rate 1000 and $3000 \mathrm{mg} / \mathrm{kg}$. Higher activities of polyphenoloxidase (PPO), peroxidase (POD) activities and total phenolic content of tubers and leaves were significantly recorded compared to control at all tested times. This was evident from reduced soft and brown rot diseases symptoms of potato spunta $c v$ treated with elicitors subsequently with tested bacteria. These results showed that the PPO, POD and total soluble phenols play a role in instructing resistance to potato soft and brown mold infections. The observed relationship between formulation and activity can lead to the rational design of nanoemulsion based systems for monoterpenes for applications in antimicrobial and agrochemical industries. Amalgamation of such economical treatments might lessen management costs and minimize the environmental pollution.
\end{abstract}

Keywords: Monoterpenes; Nanoemulsions; Antimicrobial activity; Plant pathogens.

\section{INTRODUCTION}

Nowadays rapid advancements in nanoformulations incorporating agrochemical agents have opened up new expectations for several industrial and consumer sectors of agricultural production ( Kah, 2015; Badawy et al., 2017; Balaure et al., 2017). This mainly to control the sensitivity and ameliorate the stability of the compounds those have high volatilization and decomposition such as plant essential oils (EOs) and their main constituents such as monoterpenes (Marei et al., 2018).The nanoformulations can, also, promote the uptake, absorption, and bioavailability of the active components in the plants and pests comparing with bulk equivalents (Qian and McClements 2011).

Nanoemulsions defined as emulsions consisting of an oil nano-scale (20 to $200 \mathrm{~nm}$ ) disseminated in the outer phase of obverse polarity by the effect of surfactants acting on the oil/water interface (Sadurní et al., 2005; Persson et al., 2014). Pesticide companies use NEs, which can either be oil-based or water-based and have standard inhibitors of herbicidal or insecticidal nanoparticles (200-400nm) (Madhuri et al., 2010; Sekhon 2014). Many techniques have been applied to the production of NEs, including low- or high-energy methods(Ultrasonic emulsification). The latter high energy method characterizes as fast and efficient capable of preparing nanoemulsions with diameters of tiny droplets and distributions of small size (Ghosh et al., 2013). Monoterpenes, the main constituents of plant essential oils, have been documented as NEs to be effective as antimicrobial agents (Ghosh et al.,2014; Zhang et al.,2014; Zahi et al., 2015; Ma et al., 2016; Li et al., 2017).

Bacterial soft rot is a dangerous disease in potato, causing considerable reduction of yield and quality.
Pectobacterium carotovorum subsp. Carotovorum, Pcc (Family: Enterobacteriaceae; Class: Gamma Proteobacteria) is soft rot bacteria and favored by low temperature and moist conditions (Chung et al., 2013). The Pectobacterium as is facultative anaerobe, no spore-forming, gram-negative enter-bacteria that cause disease in several vegetable crops (Agrios 2005). The virulence of Pcc is dependent on the production and secretion of pectinases and cellulases as plant cell wall-degrading enzymes (Verma et al., 2017). Plants that vegetative propagated such as potato was extremely infected, where the bacteria can spread from plant to plant (Pérombelon 2002).

Potato brown rot is caused by the bacterium Ralstonia solanacearum (Family: Ralstoniaceae; Class: Betaproteobacteria). This disease represents a serious threat to the potato production in many countries, especially in cosy growing areas and cause marketable yield loss (Kabeil et al.,2008; Mansfield et al., 2012). Disease resistance in plants depends upon slowing down ,suppressing or halting infection through the activation of several arrays of defense responses. It like many phytopathogenic bacteria produce multiple extracellular plant cell wall degrading enzymes. Some of these enzymes have been implicated as virulence factors contributing to the pathogen ability to invade and colonize host tissues causing the wilt disease (Liu et al.,2005; Leonard et al., 2017).

Therefore, the aim of this article was to prepare and characterize nanoemulsions containing $(R)$-carvone, cinnamaldehyde, citral, geraniol and pulegone in order to enhance their antimicrobial effects against plant pathogenic bacteria $P$. carotovora and $R$. solanacearumin in vitro and in vivo studies. The interactive effect between the bacterial pathogens and the host plant were studied in 
details through determination of the disease index and peroxidase (POD), polyphenol oxidase (PPO) and total soluble phenolic content as defense related enzymes.

\section{MATERIALS AND METHODS}

Chemicals and reagents

Five monoterpenes (Figure 1) include cinnamaldehyde (98\%), geraniol (98\%) and pulegone
(92\%) were purchased from ACROS Organics Company, New Jersey, USA whereas $(R)$-carvone $(98 \%)$, and citral (95\%) were purchased from Sigma-Aldrich Chemical Co. (St. Louis, MO, USA). Zenga fungicide $(10 \% \mathrm{Cu}$ $+5 \%$ Metalaxyl $+10 \%$ Mancozeb) was purchased from Bio Nano Technology Company, Nubaria, El-Behera. All other solvents and reagents were used without further purification.

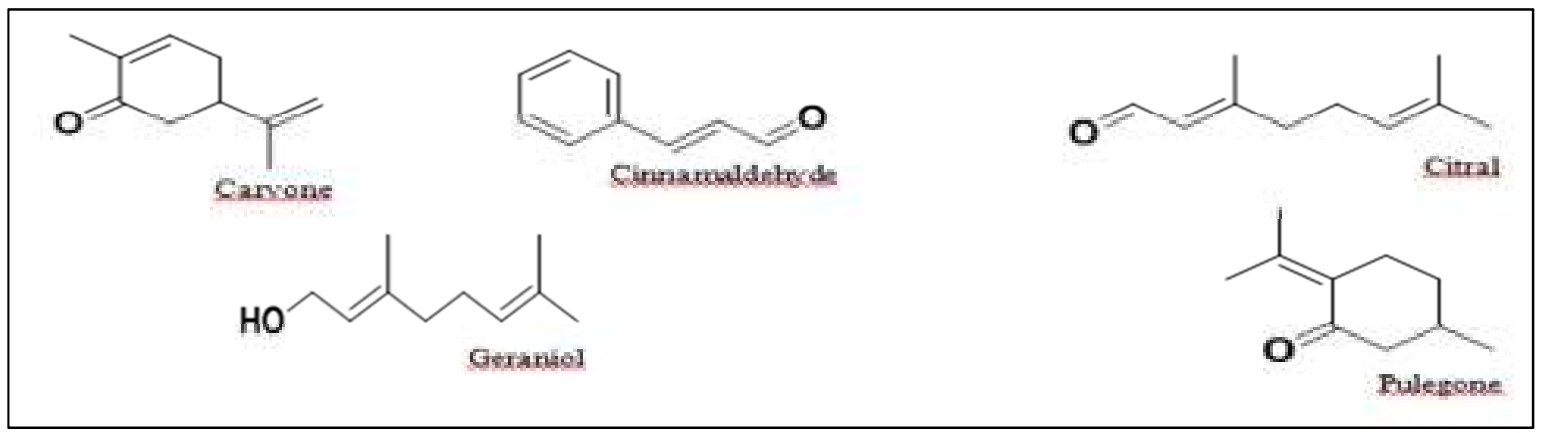

Figure 1. The chemical structure of the tested monoterpenes.

\section{Bacterial cultures}

Bacteria of soft rot and brown rot disease were obtained from Plant Pathology Department, Faculty of Agriculture, Damanhour University, Egypt. The bacterium $P$. carotovorum was maintained on the surface of plates containing NA medium (peptone 10 , meat extract 5 , sodium chloride 2.5 and agar $10 \mathrm{~g} / \mathrm{L}$ in distilled water) and the plates were incubated for $48 \mathrm{~h}$ at $37^{\circ} \mathrm{C}$ (Atlas 2005). It was purified through a single colony isolation technique. While, oozes of infected potato tubers with $R$. solanacearumin were placed in sterile water, a loopful of bacterial suspension was streaked on tetrazolium agar medium (Abo-El-Dahab and El-Goorani 1969). Medium was composed of peptone $5 \mathrm{~g}$, beef extract $3 \mathrm{~g}$, glycerol $20 \mathrm{ml}$, agar $15 \mathrm{~g}$, distilled water 1L and $0.05 \%$ tetrazolium agar medium $(\mathrm{pH} 7.0)$ and incubated for $48 \mathrm{~h}$ at $37^{\circ} \mathrm{C}$. Identification was carried out according to Bergey's Manual of Systematic Bacteriology (Garrity et al., 2005). All cultural, morphological, physiological and biochemical characteristics of the bacteria were performed (Klement et al., 1990; Cowan and Steel 2004).

\section{Preparation of nanoemulsions}

Five oil-in-water $(\mathrm{O} / \mathrm{W})$ nanoemulsions containing monoterpenes concentration of $5 \%$, solvent, surfactant and deionized water were prepared using a high-energy ultrasonication method (Badawy et al.,2017). The raw emulsions were first prepared by stirring, then emulsification was performed using a high-energy ultrasonic process (Figure 2, Table 1).

Emulsion was formed by dropping monoterpenes which dissolved in DMSO in a water phase containing tween 80 as a surfactant under continuous stirring by a magnetic stirrer at $4000 \mathrm{rpm}$ for $30 \mathrm{~min}$. The emulsions were then subjected to ultrasonic emulsification under optimum conditions (Badawy et al.,2017). The optimal conditions for ultrasonic emulsification involved sonication power $75 \mathrm{kHz}$ and pulses or cycles, 9 cycle /sec for $15 \mathrm{~min}$ (Ultrasonic Homogenizers HD 2070) (Anjali et al.,2012).
Transmission electron microscopy (TEM)

The morphology of the prepared NEs was envisaged by TEM (JEOL JSM-1200EX II, USA). Samples $(50 \mu \mathrm{L})$ were added to 200-mesh form war-coated copper TEM sample holders and were then stained with phosphotungstic acid (1.5\%). Excess liquid was removed and the TEM samples were observed with TEM equipped with $20 \mu \mathrm{m}$ aperture at $67 \mathrm{kV}$.

\section{Zeta potential}

The electrophoretic properties of nanoemulsion droplets were measured by Zeta sizer nano system (Malvern instrument Ltd., UK). The nanoemulsion was transferred to zeta-potential cell and mustered at $25^{\circ} \mathrm{C}$ (Honary and Zahir 2013).

\section{Droplet size and poly dispersity index (PDI)}

The droplet size and poly dispersity index (PDI) of NEs were measured by a dynamic light scattering (DLS) at room temperature. Samples prior to measurements were diluted to $10 \%$ with deionized water. The size of the droplet( in nanometer) was calculated as outlined by Hamed et al., ( 2016).

\section{Viscosity and pH}

The dynamic viscosity $(\eta)$ was measured by a Rotary Myr VR 3000 viscometer using L4 spindle at $200 \mathrm{rpm}$ at $25^{\circ} \mathrm{Cand}$ the data expressed in $\mathrm{mPa}$.s. The $\mathrm{pH}$ value was measured by digital $\mathrm{pH}$ meter (Mi 151 Martini Instruments, Model Mi 150, UK).

\section{Thermodynamic stability}

The nanoemulsions were tested for stability at centrifugation, freeze thaw cycle and also at room temperature. Nanoemulsions were centrifuged at $5000 \mathrm{rpm}$ for $30 \mathrm{~min}$ and were observed for phase separation and successful combinations were tested (Kadhim and Abbas 2015). Stability test at freeze thaw cycle was carried out by storage of the nano-formulations at $-21^{\circ} \mathrm{C}$ for $24 \mathrm{~h}$ and then at $21^{\circ} \mathrm{C}$ until melt for also $24 \mathrm{~h}$ (Kadhim and Abbas 2015), separation or creaming layer was examined. In addition, stability at room temperature was performed. All measurements were performed in triplicate. 
Table 1. Preparation conditions of different nanoemulsions containing monoterpenes

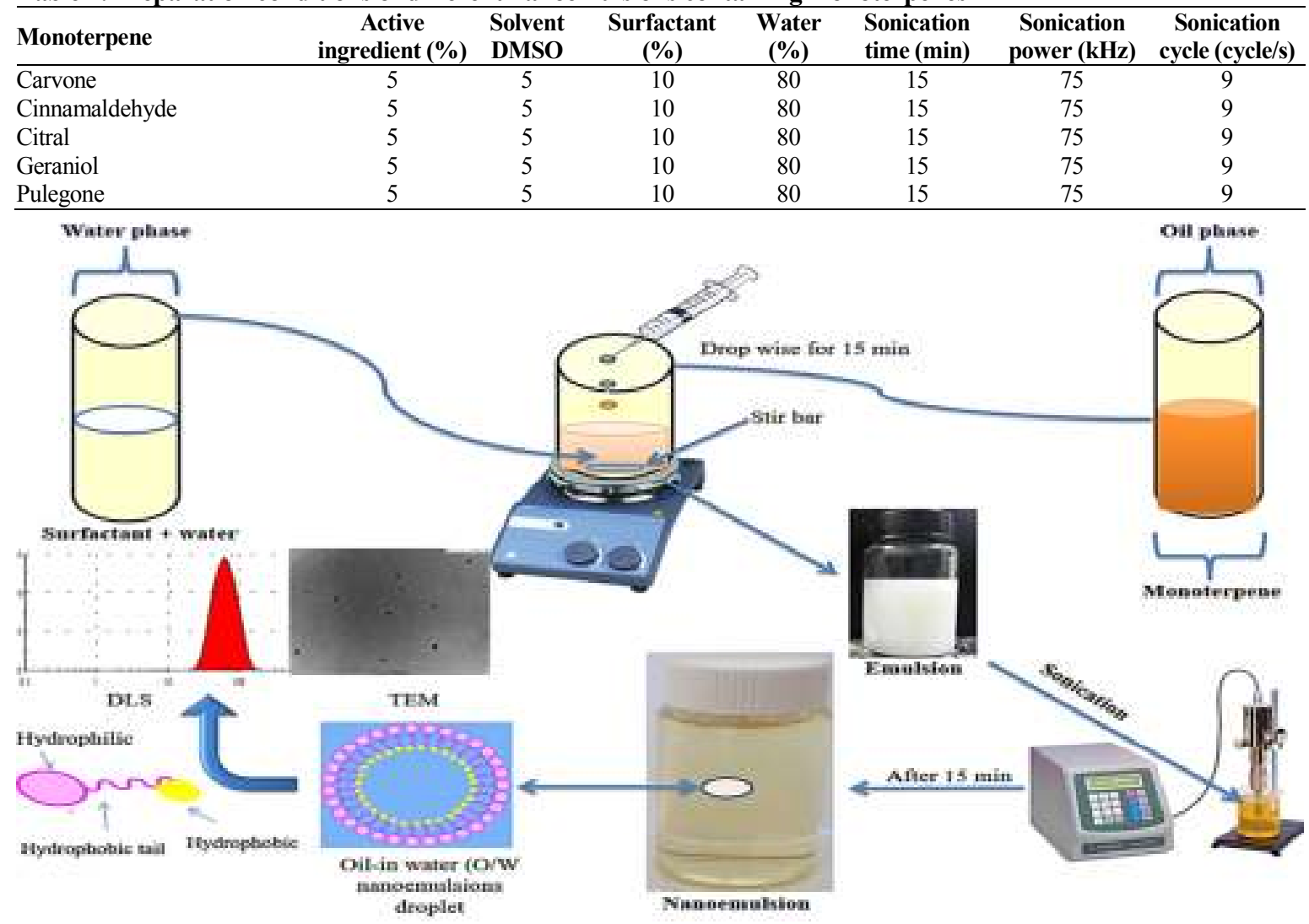

Figure 2. Schematic presentation shows preparation of different nanoemulsions containing monoterpenes.

Antibacterial assay

Minimum inhibitory concentration (MIC) assay

The in vitro antibacterial activity of pure and nanoemulsions were assayed using NA dilution method according to the European committee for antimicrobial susceptibility testing (EUCAST 2000) against $P$. carotovorum sub carotovorum, and $R$. solanacearum. The tested monoterpenes were dissolved in tween 20 and Zenga was used as a reference fungicide. Appropriate volumes of the stock solutions were added to molten NA to obtain a range of concentrations (10 to $10000 \mathrm{mg} / \mathrm{L}$ ) before pouring to petri dishes. After solidifications, bacterial cultures (approximately $10^{8} \mathrm{CFU} / \mathrm{mL}$ ) was spotted (ten spots per each plate) using $2 \mu \mathrm{L}$ standard loop on the surface of agar. The inoculums spots were allowed to dry before inverting the plates for incubation at $37^{\circ} \mathrm{C}$ for $24 \mathrm{~h}$. Parallel controls were maintained with distilled water and tween 20 mixed with NA medium. The MIC was determined as lowest concentration of monoterpenes showing no visible bacterial growth in the agar plates.

Activity of NE-cinnamaldehyde on enhancing resistance of potato leaves against $R$. solanacearum

Tubers were obtained from the International Potato Center, Kafr El-Zayat, Gharbiya Governorate, Egypt. R. solanacearum isolate was tested for pathogenicity on spunta $c v$ potato, which was known to be highly susceptible. Surfaces of the aforementioned cultivar potato tubers were sterilized with $70 \%$ ethanol for 5 minutes then washed with sterile water and planted in plastic pots $(15 \mathrm{~cm}$ diameter) filled with sterile peat moss and clay (one tuber per pot) in a green house at $25 \pm 2^{\circ} \mathrm{C}$. After $4-5$ weeks, Foliar spraying until draining with $\mathrm{NE}$ cinnamaldehyde at rate, $1000 \mathrm{mg} / \mathrm{L}$ (NC-1000) and $3000 \mathrm{mg} / \mathrm{L}(\mathrm{NC}-3000)$ was applied. The treatment was replicated three times. Plants sprayed with water used as a control negative (un- inoculated, UU) and control positive(inoculated,UI) (Montesano et al.,2005). Disease severity of inoculated leaves was assessed after fifteen days of inoculation and severity of wilting was recorded daily on the scale as follows: $1=$ no symptoms, $2=$ one leaf wilted, $3=$ two or three leaves wilted, $4=$ four or more leaves wilted, and $5=$ plant dead $(\mathrm{He}$, 1983).

Activity of NE-cinnamaldehyde on enhancing resistance of potato tubers against $P$. carotovorum.

Tubers of spunta $c v$ potato (about $60 \mathrm{~g}$ in weight) were thoroughly washed then immersed in $\mathrm{NC}$ cinnamaldehyde at rate, 1000 and $3000 \mu \mathrm{g} / \mathrm{mL}$ for 60 min. After drying, tubers were kept at room temperature for one day before being inoculation (Hajhamed et al.,2007). Bacterial suspension $\left(10^{8} \mathrm{cfu} / \mathrm{mL}\right)$ was prepared from $48 \mathrm{~h}$ old culture. Tubers were prepared and sterilized then inoculated by bacterial suspension Inoculated slices were kept for $48 \mathrm{~h}$ in an incubator at $37^{\circ} \mathrm{C}$. Tubers immersed in water were used as control negative (UU), but inoculated with $P c$ isolate used as control positive (UI). After two days of incubation, the diameters of rotted area $(\mathrm{cm})$ were measured (Hollis and Goss 1950). Three replicates of slices were used. 
Effect of NE- cinnamaldehyde on defense related enzymes activities

Spunta $c v$ was used to determine the effect of elicitors on defense related enzymes activities such as, PPO and POD and total phenolic content. Tubers and leaves were treated with NE cinnamaldehyde doses as previously mentioned. The samples were taken from around infection site. Enzymes activities were evaluated in samples after $0,6,12,24$ and $48 \mathrm{~h}$ post inoculations and each treatment was triplicated. One gram of the leaves or tubers was homogenized in $2 \mathrm{~mL}$ of $0.1 \mathrm{M}$ sodium phosphate buffer ( $\mathrm{pH}$ 6.5) in a pre-chilled pestle and mortar. The homogenate was centrifuged at 10,000 rpm for 15 min at $4^{\circ} \mathrm{C}$ and the supernatant served as an enzyme source. Polyphenol oxidase (PPO) and peroxidase (POD) activities of leaves and tubers were measured by the method of Mayer et al.,(1966) and Hammerschmidt et al.,(1982), respectively, and were expressed as change in absorbance (OD) $\mathrm{min}^{-1} \mathrm{~g}^{-1}$ of fresh tissue. While, total phenolic contents of leaves and tubers (catechol equivalent/g of fresh tissue) were determined by the method of Zieslin and Ben Zaken,(1993) .

\section{Statistical analysis}

Statistical analysis was performed using SPSS 21.0 software. The data of enzymes activity were analyzed by one-way ANOVA. Duncan's Multiple Range Test (DMRT) was employed to test for significant between the treatments at $\mathrm{P}<0.05$ (Duncan, 1955).

\section{RESULTS AND DISCUSSION}

\section{Characterization of nanoemulsions}

\section{Physical and thermodynamic stabilities}

The thermodynamic characterizations are presented in Table 2. The nanoemulsions were stable at centrifugation of $5000 \mathrm{rpm}$, heating cycle, and freezethaw cycle for 4 weeks. No creaming or phase separation was observed on these formulations. It is well known that centrifugation can speed the rate of sedimentation indicting that degradation of any emulsion may be referred to the gravitational force action. Oil/Water emulsion often appears compared to deposition of precipitation due to low oil droplet density rather than aquatic medium. It is important to have good physical properties during long-term storage, If NEs are to be used as an antimicrobial delivery systems, (Tadros et al., 2004).

\section{Viscosity and pH}

The NEs $R$-carvone, cinnamaldehyde, citral, geraniol and pulegone have viscosity values of 3.33, 7.00, $2.67,4.33$ and $2.80 \mathrm{mPa} . \mathrm{s}$, orderly (Table 2). The $\mathrm{pH}$ value of the tested five formulations ranged from 6.0 to 6.5 . The $\mathrm{pH}$ can results in a great effect on the stability of NEs (Badawy and Rabea 2017). Viscosity strongly affected by several factors such as disperse phase volume fraction, colloidal interactions, droplet size , archeology of component phases, and droplet charge (El-Mohamedy et al., 2015; McClements 2015; Pal 2011).

Table 2. Characterizations and thermodynamic stability of different NEs-monoterpenes

\begin{tabular}{|c|c|c|c|c|c|c|c|c|c|}
\hline \multirow[b]{2}{*}{ Nanoemulsion } & \multicolumn{5}{|c|}{ Characterizations } & \multicolumn{4}{|c|}{ Thermodynamic stability } \\
\hline & $\begin{array}{c}\mu \\
\text { (mPa.s) } \\
\pm \text { SE }\end{array}$ & pH & $\begin{array}{c}\text { Droplet } \\
\text { diameter } \\
(\mathbf{n m}) \pm \mathrm{SE}\end{array}$ & $\begin{array}{c}\text { PDI } \\
\pm \\
\text { SE } \\
\end{array}$ & $\begin{array}{c}\text { Zeta } \\
\text { potential } \\
(\mathrm{mV})\end{array}$ & $\begin{array}{c}\text { Room } \\
\text { temperature } \\
\left(25^{\circ} \mathrm{C}\right) \\
\end{array}$ & $\begin{array}{c}\text { Centrifugation } \\
\text { (5000 rpm) }\end{array}$ & $\begin{array}{c}\text { Freezing } \\
\text { cycle } \\
\left(-21^{\circ} \mathrm{C}\right)\end{array}$ & $\begin{array}{c}\text { Heating } \\
\text { cycle } \\
\left(21^{\circ} \mathrm{C}\right)\end{array}$ \\
\hline$\overline{\text { Carvo }}$ & $3.33 \pm 0.34$ & 6.5 & $67.23 \pm 0.21$ & $0.177 \pm 0.01$ & +0.816 & $\sqrt{ }$ & $\sqrt{ }$ & $\sqrt{ }$ & $\sqrt{ }$ \\
\hline Cinnamaldehyde & $7.00 \pm 0.58$ & 6.1 & $128.07 \pm 1.34$ & $0.322 \pm 0.01$ & -0.052 & $\sqrt{ }$ & $\sqrt{ }$ & $\sqrt{ }$ & $\sqrt{ }$ \\
\hline Citral & $2.67 \pm 0.34$ & 6.0 & $56.64 \pm 0.13$ & $0.130 \pm 0.01$ & -0.216 & $\sqrt{ }$ & $\sqrt{ }$ & $\sqrt{ }$ & $\sqrt{ }$ \\
\hline Geraniol & $4.33 \pm 0.34$ & 6.5 & $176.00 \pm 3.21$ & $0.630 \pm 0.08$ & -1.110 & $\sqrt{ }$ & $\sqrt{ }$ & $\sqrt{ }$ & $\sqrt{ }$ \\
\hline Pulegone & $2.80 \pm 0.20$ & 6.0 & $58.83 \pm 0.15$ & $0.311 \pm 0.01$ & -0.572 & $\sqrt{ }$ & $\sqrt{ }$ & $\sqrt{ }$ & $\sqrt{ }$ \\
\hline
\end{tabular}

\section{Droplet size and PDI}

Droplet size and PDI are presented in Table 2 and Figure 3. Results reflected that NEs recorded droplet size of $67.23 \mathrm{~nm}$ for $R$-carvone, $128.07 \mathrm{~nm}$ for cinnamaldehyde, $56.64 \mathrm{~nm}$ for citral, $176.00 \mathrm{~nm}$ for geraniol and $58.83 \mathrm{~nm}$ for pulegone. This result demonstrated that preparation in the nanometric size for all compounds were successful. NEs $R$-carvone, citral and pulegone recorded the lowest value of droplet diameter size $(67.23,56.64$ and $58.83 \mathrm{~nm}$, respectively) compared to NEs cinnamaldehyde and geraniol (128.07 and 176.00, respectively). Generally, the range of 10 to $500 \mathrm{~nm}$ was the same range which the average droplet size of $\mathrm{O} / \mathrm{W}$ nanoemulsions falls within it. Li and Chiang (2012), reported that the NEs D-limonene reflected a droplet size smaller than $100 \mathrm{~nm}$.

The PDI values were $0.177,0.322,0.130,0.630$ and 0.311 for NEs $R$-carvone, cinnamaldehyde, citral, geraniol and pulegone, respectively. This indicated that all NEs had a relatively narrow range of size distribution. In addition, NEs $R$-carvone and citral are the highest homogeneous compared to NEs cinnamaldehyde, geraniol and pulegone. This finding is proved by Shakeel et al.,(2007), who reported that the PDI value remained less than 0.2 exhibits the relative homogeneity of the NEs and PDI $>0.3$ indicating system heterogeneity.

\section{Transmission electron microscopy (TEM)}

Figure 4 shows a microscopic image of TEM of NEs which shows a spherical shape in NEs that provides the same appearance of oil in water type. It was noticed that the droplet size of TEM analysis seemed to correlate with the range of droplet diameter obtained using Zetasizer. The discrepancies in morphology might be related to the composition of dispersed phase of each formulation (Li and Chiang 2012; Liu and Wu 2010).

\section{Zeta potentials (electrophoretic properties)}

The zeta potential values were $+0.816,-0.052$, $0.216,-1.110$ and $-0.572 \mathrm{mV}$ for the NEs $R$-carvone, cinnamaldehyde, citral, geraniol and pulegone, respectively (Table 2). Increasing the surface charge improve the emulsions stability because of the increase of repelling forces between droplets against contraction and coalescence (Stachurski and Michalek 1996). Li and Lu 
(2016), found that the NE D-limonene $(10.0 \%)$ at the $\mathrm{pH}$ 6.4 recorded approximately $-35 \mathrm{mV}$ as a zeta potential.

The differences in the dissociation degree and ability for compound ionization is the reason of the negatively charged zeta potentials of emulsions and NEs formulated with different monoterpenes (Bonilla et al., 2012). However, only short-term stability was noticed for NEs droplets with zeta potentials of $\pm 20 \mathrm{mV}$, but the droplet tend to come together (Mishra et al., 2009).
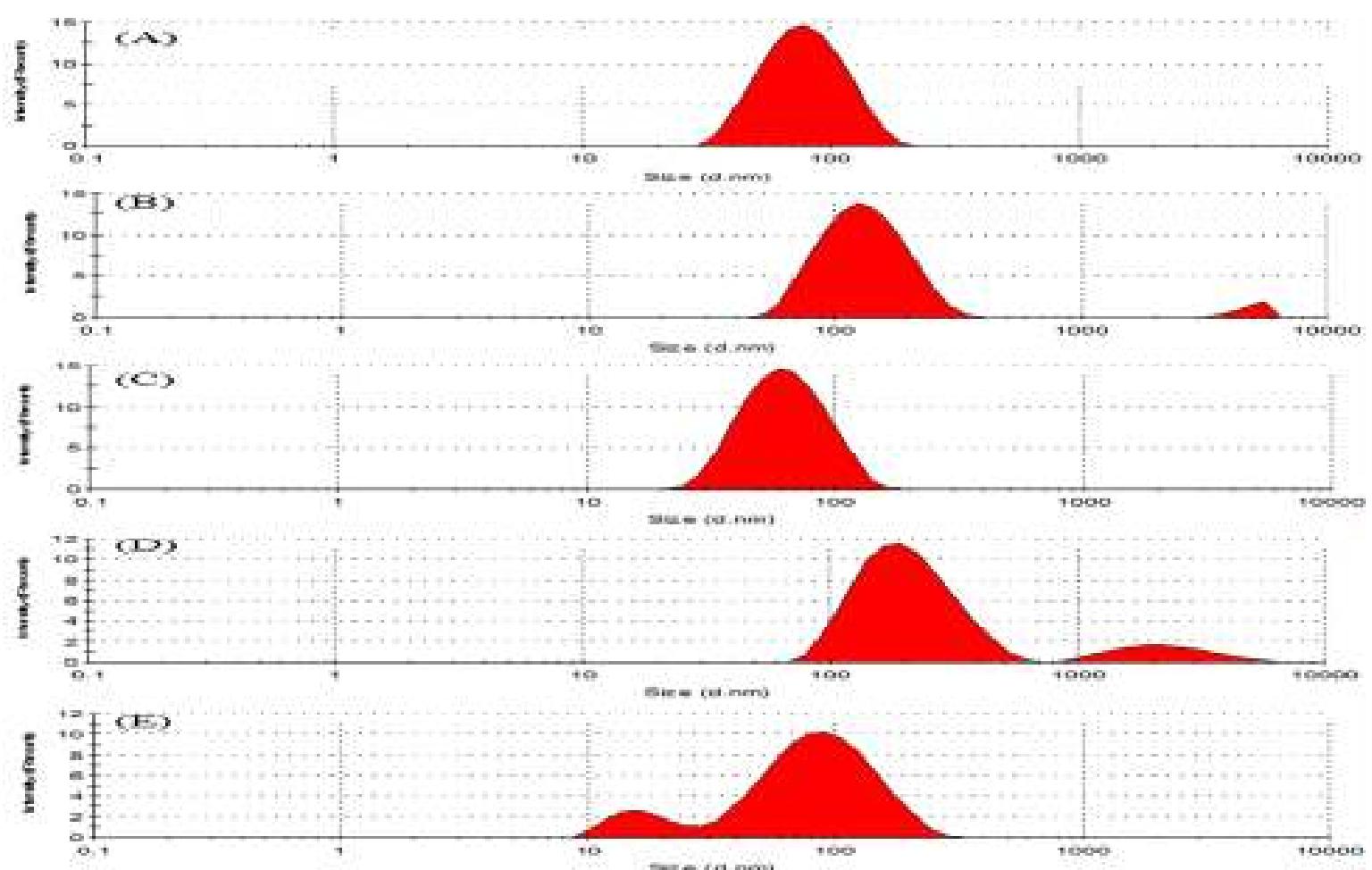

Figure 3. Droplet size distribution measurement by dynamic light scattering (DLS) of NEs monoterpenes. A: (R)carvone, B: cinnamaldehyde, C: citral, D: geraniol and E: pulegone.

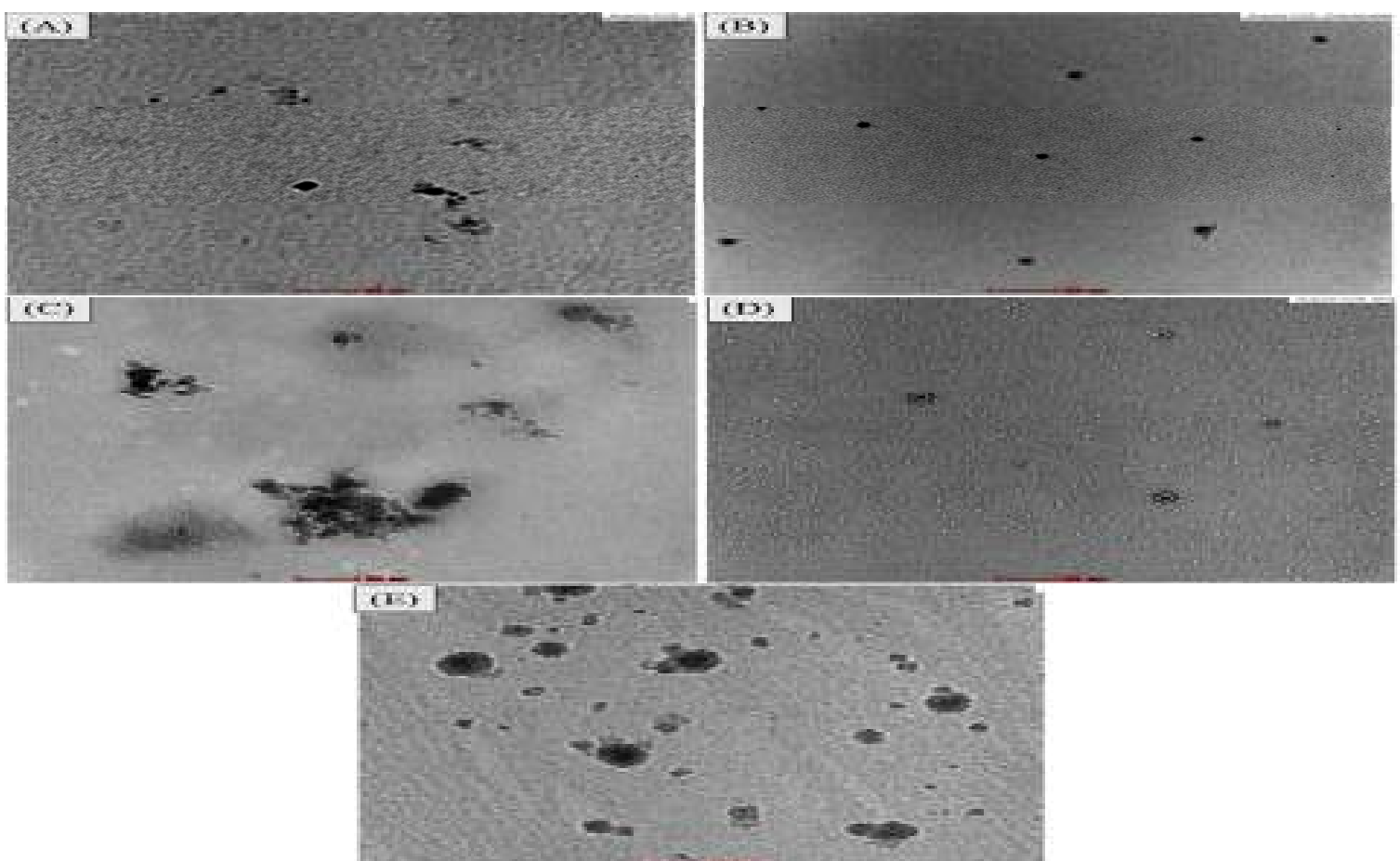

Figure 4. TEM image of NEs monoterpenes. A: (R)-carvone, B: cinnamaldehyde, C: citral, D: geraniol and E: pulegone.The TEM was performed on a JEOL JSM-1200EX-electron microscopy operating at an acceleration voltage of $67 \mathrm{kV}$ with $20 \mu \mathrm{m}$ aperture. 
Isolation and identification of bacteria

The two tested bacterial have rods, non spore, gram negative and motile (Table 3 ). Positive reaction for catalase activity, gelatin liquefaction and acid production from lactose, Arabinose, Mannose, Raffinose and Sorbitol was detected for $P$. carotovorum and $40^{\circ} \mathrm{C}$ for $R$. solanacearum. Furthermore, both two tested bacterial grow at $37^{\circ} \mathrm{C}$ However, negative reaction for hydrolysis of starch and inability to produce acids from maltose, adonitol and dextrin were detected.

Table 3. Some morphological, physiological and biochemical activities of $P$. carotovorum and $R$. solanacearum.

\begin{tabular}{lcc}
\hline Characteristics & \multicolumn{2}{c}{ Bacterial isolates } \\
\cline { 2 - 3 } Cell shape (Rods, single) & P. carotovorum & R. solanacearum \\
Sporulation & + & + \\
Motility & + & - \\
Gram reaction & - & + \\
Catalase activity & + & - \\
Gelatin liquefaction & + & + \\
Hydrolysis of starch & - & - \\
Sensitivity to erythromycin & - & + \\
Anaerobic growth & + & + \\
Kovac's oxidase & - & - \\
Growth on NaCl 6\% & + & $40 \mathrm{C}^{\mathrm{o}}$ \\
Growth at & $37 \mathrm{C}^{\circ}$ & + \\
Production of acid from & & + \\
\multicolumn{1}{c}{ Arabinose } & + & + \\
Lactose & + & - \\
Manose & + & - \\
Maltose & - & + \\
Adonitol & - & - \\
Raffinose & + & + \\
Sorbitol & + & + \\
Dextrin & - & + \\
Sucrose & & + \\
\hline
\end{tabular}

$+=$ positive reaction. $-=$ negative reaction.

Antibacterial activity

The MICs of nanemulsion and normal cinnamaldehyde showed significantly higher inhibition (MIC ranged from 60 and $275 \mathrm{mgL}^{-1}$ ) against $P$. carotovorum than $R$. solanacearum (MIC ranged from 100 and $\left.450 \mathrm{mgL}^{-1}\right)$ (Table 4). Several studies have reported enhancing the physical properties and antimicrobials of NEsessential oils (EOs) compared to conventional emulsions (Buranasuksombat et al. 2011; São Pedro et al. 2013; Bilia et al. 2014; Guerra-Rosas et al. 2017). Results displayed that the NE was more effective as an antibacterial activity compared to normal monoterpenes. This is presumably due to the fact that the nanostructures of fat particles are able to bring primary oil to the surface of the cell membrane, while pure oil (low water solubility) failed or cannot easily interact with cell membranes. The results obtained are previously confirmed with (Zhang et al., (2014), who reported $n$ that NEs-EOs markedly enhanced antibacterial activity, Dlimonene. Lambert et al.,(2001), clarified that the EOs containing carvacrol and thymol as monoterpenes, such as thyme oil exhibited a strong bactericidal action. Furthermore, eugenol and citral, the main components of clove, lemon or rosewood EO, were found, respectively to disrupt against a wide spectrum of microorganisms (Friedman et al., 2004). Other aromatic compounds such as linalool, pinene, geraniol and borneol showed less inhibition effect against bacteria (Zachariah and Leela 2006). Hamouda and Baker (2000) reported the NE soybean oil had a good bactericidal activity against gram-positive bacteria.
Table 4. Minimum inhibitory concentration (MIC) of tested normal monoterpenes and their nanoemulsions against plant pathogenic bacteria $P$. carotovorum and $R$. solanacearum.

\begin{tabular}{|c|c|c|c|}
\hline \multirow{2}{*}{ Treatment } & & \multicolumn{2}{|c|}{ Minimum inhibitory concentration $(\mathrm{mg} / \mathrm{L})$} \\
\hline & & P. carotovorum & R. solanacearum \\
\hline \multirow[b]{2}{*}{ Carvone } & $\mathrm{N}$ & 1000 & 1250 \\
\hline & $\mathrm{NE}$ & 400 & 500 \\
\hline \multirow{2}{*}{\multicolumn{2}{|c|}{ Cinnamaldehyde $\stackrel{\mathrm{N}}{\mathrm{NE}}$}} & 275 & 450 \\
\hline & & 60 & 100 \\
\hline \multirow{2}{*}{ Citral } & $\mathrm{N}$ & 300 & 500 \\
\hline & $\mathrm{NE}$ & 100 & 170 \\
\hline \multirow{2}{*}{ Geraniol } & $\mathrm{N}$ & 350 & 575 \\
\hline & $\mathrm{NE}$ & 160 & 300 \\
\hline \multirow{3}{*}{$\begin{array}{l}\text { Pulegone } \\
\text { Zenga }\end{array}$} & $\mathrm{N}$ & 650 & 1000 \\
\hline & $\mathrm{NE}$ & 200 & 600 \\
\hline & & 50 & 90 \\
\hline
\end{tabular}

Effect of NE cinnamaldehyde defense related enzymes activity and total phenolic content of potato tubers and leaves.

The role of PPO, POD and total phenolic content on imparting resistance to soft and brown rot diseases in potato tubers and leaves was considered in this study. Defense reactions were evaluated after $0,6,12,24$ and $48 \mathrm{~h}$ post inoculations by $P$. carotovorum and $R$. solanacearum after the treatment with NE-cinnamaldehyde. This NE was the most significantly effective on reducing the rotted area diameters in tubers inoculated with $P$. carotovorum and wilt disease index in leaves inoculated with $R$. solanacearum compared to positive control (Table 5).

Table 5. Pathological reaction of potato tubers to $P$. carotovorum and wilt disease index developed on potato leaves inoculated with $R$. solanacearum.

\begin{tabular}{lcc}
\hline \multirow{2}{*}{ Treatment } & Diameterrotted area (cm) & Wilt disease index \\
\cline { 2 - 3 } & $\boldsymbol{P}$. carotovorum & $\boldsymbol{R}$. solanacearum \\
\hline UU & $0.00 \pm 0.00^{\mathrm{d}}$ & 1 \\
UI & $3.57 \pm 0.10^{\mathrm{a}}$ & 5 \\
NC-1000 & $1.22 \pm 0.67^{\mathrm{c}}$ & 2 \\
NC-1000 & $2.22 \pm 0.11^{\mathrm{b}}$ & 4 \\
\hline
\end{tabular}

UU, untreated uninoculated; UI, untreated inoculated; NC-1000, Nanoemulsion cinnamalehyde at $1000 \mathrm{mg} / \mathrm{L}$, NC-3000, Nanoemulsion cinnamalehyde at $3000 \mathrm{mg} / \mathrm{L}$, *Data with the same letter(s) within a column are not significantly different according to Duncan's a new multiple range test.

Results in Table 6 showed that the PPO and POD activities in infected potato tubers were increased by the infection with $P$. carotovorum compared with the positive control. NE-cinnamaldehyde at rate $1000 \mathrm{mg} / \mathrm{L}$ (NC-1000) was the most effective treatment, followed by NEcinnamaldehyde at rate $3000 \mathrm{mg} / \mathrm{L}$ (NC-3000) and they, significantly, raised the values of the total phenolic content as compared to the control. Both applied treatments, significantly, enhanced enzymes activity comparing with the control. Results also showed that the PPO and POD activities in NC-1000 treatment was significantly increased under all the tested time. However, application of NC-3000 exhibited the highest of both PPO and POD activities at $12 \mathrm{~h}$ are 0.67 and 0.75 (OD min $\mathrm{g}^{-1}$ fresh tissue, respectively), then, declined. An increase of total phenolic content in NC1000 level was detected at $24 \mathrm{~h}\left(95.84 \mu \mathrm{g}\right.$ of catechol $\mathrm{g}^{-1}$ fresh tissue), then, declined, whereas; total phenolic increased with the time at rate NC-3000. 
Likewise, data in Table (7) revealed that PPO and POD activity and total phenolic content were significantly increased with NE cinnamaldehyde by the infection with $R$. solanacearum in potato leaves compared with control. PPO and POD activities in NC-1000 treatment was showed highest effect at $42 \mathrm{~h}$ are 3.89 and 1.37(OD min $\mathrm{g}^{-1}$ fresh tissue, respectively), then, declined. However, NE cinnamaldehyde at rate $3000 \mathrm{mg} / \mathrm{L}$ exhibited the highest of both PPO and POD activities at $6 \mathrm{~h}$ are 2.78 and 1.12 (OD $\min \mathrm{g}^{-1}$ fresh tissue, respectively), then, declined. An increase of total phenolic content in doses NC-1000 and NC3000 was detected at $24 \mathrm{~h}(140.84$ and $126.39 \mu \mathrm{g}$ of catechol $\mathrm{g}^{-1}$ fresh tissue), then, declined, and increased with the time at rate $\mathrm{NC}-3000$ at $48 \mathrm{~h}$. The resistance of the potato was associated with high PPO and POD enzyme activities. In addition, higher activation of total soluble phenols (high concentration values ) were detected indicating. These obtained results demonstrate that the PPO, POD, and total phenolic have an important role in inducing resistance to potato soft and brown rot infections. PPO catalyzes oxidation of phenols to quinones causing highly toxic to the microorganisms than the original phenolic compounds (Gandía-Herrero et al.,2005).The increase in the activities of oxidant defensive enzymes such as, POD and PPO were associated with resistance to E. carotovora (Ngadze et al.,2012).

Higher activation of the defense related enzymes; POD, PPO and total soluble phenols were detected due to the interactive effect between the pathogen and the host plant which induces some changes in cell metabolism (Vance et al. 1980; Fry 1982; Ngadze et al.,2012). Phenols and their oxidative products were shown to inhibit $P$. carotovorum (Lyon and McGill 1989; Weber et al.,1996) and the cell wall degrading enzyme activity of the bacteria (Lyon 1989).

Table 6. Polyphenol oxidase (PPO), peroxidase (POD) activity and total phenolic content in potato tubers after treatment with NE cinnamaldehyde followed by inoculation with $P$. carotovorum.

\begin{tabular}{lccccc}
\hline Treatment & \multicolumn{5}{c}{ Time (h) } \\
\cline { 2 - 6 } & $\mathbf{0}$ & $\mathbf{6}$ & $\mathbf{1 2}$ & $\mathbf{2 4}$ & $\mathbf{4 8}$ \\
PPO activity $\left(\mathrm{ODmin}^{-1} \mathrm{~g}^{-1}\right.$ fresh tissue) & & & & \\
UU & $0.45 \pm 0.01^{\mathrm{a}}$ & $0.51 \pm 0.01^{\mathrm{c}}$ & $0.52 \pm 0.01^{\mathrm{a}}$ & $0.54 \pm 0.00^{\mathrm{a}}$ & $0.55 \pm 0.00^{\mathrm{c}}$ \\
UI & $0.39 \pm 0.00^{\mathrm{e}}$ & $0.36 \pm 0.00^{\mathrm{d}}$ & $0.34 \pm 0.00^{\mathrm{e}}$ & $0.33 \pm 0.00^{\mathrm{e}}$ & $0.28 \pm 0.02^{\mathrm{d}}$ \\
NC-1000 & $0.63 \pm 0.00^{\mathrm{a}}$ & $0.75 \pm 0.00^{\mathrm{a}}$ & $0.77 \pm 0.00^{\mathrm{a}}$ & $0.78 \pm 0.00^{\mathrm{a}}$ & $0.79 \pm 0.02^{\mathrm{a}}$ \\
NC-3000 & $0.51 \pm 0.00^{\mathrm{c}}$ & $0.60 \pm 0.01^{\mathrm{b}}$ & $0.67 \pm 0.01^{\mathrm{c}}$ & $0.59 \pm 0.00^{\mathrm{c}}$ & $0.53 \pm 0.01^{\mathrm{c}}$ \\
\hline POD activity $\left(\mathrm{OD} \mathrm{min}^{-1} \mathrm{~g}^{-1}\right.$ fresh tissue) & & & & \\
UU & $0.90 \pm 0.01^{\mathrm{c}}$ & $0.96 \pm 0.00^{\mathrm{c}}$ & $0.98 \pm 0.00^{\mathrm{c}}$ & $1.03 \pm 0.00^{\mathrm{c}}$ & $1.06 \pm 0.00^{\mathrm{c}}$ \\
UI & $0.51 \pm 0.00^{\mathrm{e}}$ & $0.50 \pm 0.00^{\mathrm{e}}$ & $0.45 \pm 0.00^{\mathrm{e}}$ & $0.41 \pm 0.00^{\mathrm{e}}$ & $0.33 \pm-.01^{\mathrm{e}}$ \\
NC-1000 & $1.00 \pm 0.00^{\mathrm{a}}$ & $1.16 \pm 0.03^{\mathrm{a}}$ & $1.25 \pm 0.00^{\mathrm{a}}$ & $1.34 \pm 0.33^{\mathrm{a}}$ & $1.48 \pm 0.04^{\mathrm{a}}$ \\
NC-3000 & $0.73 \pm 0.00^{\mathrm{d}}$ & $0.88 \pm 0.01^{\mathrm{d}}$ & $0.75 \pm 0.00^{\mathrm{d}}$ & $0.61 \pm 0.00^{\mathrm{d}}$ & $0.59 \pm 0.00^{\mathrm{d}}$ \\
Total Phenolic $\left(\mu \mathrm{g}\right.$ of catchole g $\mathrm{g}^{-1}$ fresh tissue) & & & & \\
UU & $48.77 \pm 0.26^{\mathrm{a}}$ & $59.43 \pm 0.17^{\mathrm{c}}$ & $51.359 \pm 0.10^{\mathrm{a}}$ & $71.39 \pm 0.29^{\mathrm{c}}$ & $83.62 \pm-.35^{\mathrm{a}}$ \\
UI & $84.33 \pm 0.12^{\mathrm{a}}$ & $60.22 \pm 0.10^{\mathrm{c}}$ & $53.51 \pm 0.66^{\mathrm{c}}$ & $78.90 \pm 1.02^{\mathrm{b}}$ & $93.83 \pm 0.20^{\mathrm{b}}$ \\
NC-1000 & $76.91 \pm 0.28^{\mathrm{b}}$ & $84.84 \pm 0.31^{\mathrm{ab}}$ & $94.15 \pm 0.25^{\mathrm{a}}$ & $97.29 \pm 0.10^{\mathrm{a}}$ & $88.26 \pm 0.12^{\mathrm{c}}$ \\
NC-3000 & $68.21 \pm 0.74^{\mathrm{c}}$ & $81.47 \pm 0.51^{\mathrm{b}}$ & $91.34 \pm 0.25^{\mathrm{b}}$ & $95.84 \pm 0.59^{\mathrm{a}}$ & $104.14 \pm 0.18^{\mathrm{a}}$ \\
\hline
\end{tabular}

UU, untreated uninoculated; UI, untreated inoculated; NC-1000, Nanoemulsion cinnamaldehyde at 1000mg/L, NC-3000, Nanoemulsion cinnamaldehyde at $3000 \mathrm{mg} / \mathrm{L}$, *Data with the same letter(s) within a column are not significantly different according to Duncan's a new multiple range test.

Table 7. Polyphenol oxidase (PPO), peroxidase(POD) activity and total phenolic content in potato leaves after treatment with NE cinnamaldehyde followed by inoculation with $R$. solanacearum.

\begin{tabular}{|c|c|c|c|c|c|}
\hline \multirow{2}{*}{ Treatment } & \multicolumn{5}{|c|}{ Time (h) } \\
\hline & $\mathbf{0}$ & 6 & 12 & 24 & 48 \\
\hline \multicolumn{6}{|c|}{ PPO activity (OD $\min ^{-1} \mathrm{~g}^{-1}$ fresh tissue) } \\
\hline UU & $1.93 \pm 0.012^{\mathrm{c}}$ & $2.02 \pm 0.10^{\mathrm{c}}$ & $2.06 \pm 0.00^{\mathrm{c}}$ & $2.10 \pm 0.01^{\mathrm{c}}$ & $2.25 \pm 0.04^{\mathrm{b}}$ \\
\hline UI & $2.05 \pm 0.01^{\mathrm{c}}$ & $1.93 \pm 0.03^{\mathrm{c}}$ & $1.25 \pm 0.00^{\mathrm{d}}$ & $1.17 \pm 0.01^{\mathrm{d}}$ & $0.97 \pm 0.01^{\mathrm{d}}$ \\
\hline NC-1000 & $3.17 \pm 0.12^{\mathrm{a}}$ & $3.48 \pm 0.09^{\mathrm{a}}$ & $3.71 \pm 0.03^{\mathrm{a}}$ & $3.89 \pm 0.01^{\mathrm{a}}$ & $3.24 \pm 0.05^{\mathrm{a}}$ \\
\hline NC-3000 & $2.52 \pm 0.06^{\mathrm{b}}$ & $2.78 \pm 0.07^{\mathrm{b}}$ & $2.77 \pm 0.02^{\mathrm{b}}$ & $2.29 \pm 0.09^{b}$ & $1.96 \pm 0.04^{\mathrm{c}}$ \\
\hline \multicolumn{6}{|c|}{ POD activity (OD $\min ^{-1} \mathrm{~g}^{-1}$ of fresh tissue) } \\
\hline UU & $0.82 \pm 0.00^{\mathrm{d}}$ & $0.84 \pm 0.00^{\mathrm{c}}$ & $0.86 \pm 0.00^{\mathrm{c}}$ & $0.88 \pm 0.00^{\mathrm{c}}$ & $0.91 \pm 0.00^{\mathrm{c}}$ \\
\hline UI & $0.83 \pm 0.00^{\mathrm{c}}$ & $0.81 \pm 0.01^{\mathrm{a}}$ & $0.77 \pm 0.00^{\mathrm{a}}$ & $0.73 \pm 0.00^{\mathrm{d}}$ & $0.70 \pm 0.00^{\mathrm{a}}$ \\
\hline NC-1000 & $1.05 \pm 0.00^{\mathrm{a}}$ & $1.16 \pm 0.00^{\mathrm{a}}$ & $1.23 \pm 0.00^{\mathrm{a}}$ & $1.37 \pm 0.04^{\mathrm{a}}$ & $1.09 \pm 0.00^{\mathrm{a}}$ \\
\hline NC-3000 & $0.97 \pm 0.00^{\mathrm{b}}$ & $1.12 \pm 0.01^{\mathrm{b}}$ & $1.08 \pm 0.00^{\mathrm{b}}$ & $1.03 \pm 0.00^{\mathrm{b}}$ & $1.00 \pm 0.00^{\mathrm{b}}$ \\
\hline \multicolumn{6}{|c|}{ Total Phenolic ( $\mu \mathrm{g}$ of catechol $\mathrm{g}^{-1}$ fresh tissue) } \\
\hline UU & $74.91 \pm 0.37^{\mathrm{d}}$ & $87.09 \pm 0.91^{\mathrm{c}}$ & $111.02 \pm 0.37^{\mathrm{c}}$ & $124.61 \pm 0.33^{\mathrm{b}}$ & $125.68 \pm 0.67^{\mathrm{b}}$ \\
\hline UI & $91.62 \pm 1.50^{\mathrm{c}}$ & $68.21 \pm 0.74^{\mathrm{d}}$ & $55.79 \pm 0.71^{\mathrm{d}}$ & $111.02 \pm 0.96^{\mathrm{d}}$ & $125.94 \pm 0.46^{\mathrm{b}}$ \\
\hline NC-1000 & $127.22 \pm 0.36^{\mathrm{a}}$ & $138.37 \pm 0.13^{\mathrm{a}}$ & $140.84 \pm 0.18^{\mathrm{a}}$ & $133.64 \pm 0.10^{\mathrm{a}}$ & $125.80 \pm 0.52^{\mathrm{b}}$ \\
\hline $\mathrm{NC}-3000$ & $124.52 \pm 0.23^{\mathrm{b}}$ & $135.38 \pm 0.36^{\mathrm{b}}$ & $126.39 \pm 0.26^{\mathrm{b}}$ & $117.67 \pm 0.35^{\mathrm{c}}$ & $134.27 \pm 0.26^{\mathrm{a}}$ \\
\hline
\end{tabular}

UU, untreated uninoculated; UI, untreated inoculated; NC-1000, Nanoemulsion cinnamaldehyde at 1000mg/L, NC-3000, Nanoemulsion cinnamaldehyde at $3000 \mathrm{mg} / \mathrm{L}$, *Data with the same letter(s) within a column are not significantly different according to Duncan's a new multiple range test.

\section{CONCLUSION}

Based on the results of this study, the conversion of monoterpenes to nanoemulsion has significantly improved its antibacterial activity against important plant pathogenic bacteria ( $P$. carotovorum and $R$. solanacearum). Nanoemulsion may be specially effective transmission systems for essential oils and their components because of their ability to facilitate the application of antimicrobials and increase the effectiveness of antimicrobials. However, as these tests were conducted in vitro, and in vivo studies on potato.

\section{Conflict of interest}

None. 


\section{REFERENCES}

Abo-El-Dahab, M and El-Goorani, M. (1969). Antagonism among strains of Pseudomonas solanacearum. Phytopathology, 59(7):1005-1007.

Agrios, GN. (2005). Plant Pathology. $5^{\text {th }}$ eds. Elsevier Academic Press, San Diego, California, USA.

Anjali, C; Sharma, Y; Mukherjee,A and Chandrasekaran, N. (2012). Neem oil (Azadirachta indica) nanoemulsion-a potent larvicidal agent against Culex quinquefasciatus. Pest Management Science, 68(2):158-163.

Atlas, RM. (2005). Handbook of media for environmental microbiology. $2^{\text {nd }}$ ed. . CRC press. Taylor \& Francis Group. Boca Raton, FL.

Badawy, ME and Rabea, EI. (2017). Chitosan and its Modifications as Biologically Active Compounds in Different Applications. Advances in Physicochemical Properties of Biopolymers (Part 2): 1 .

Badawy, ME; Saad, A-FS; Tayeb, E-SH; Mohammed, SA and Abd-Elnabi, AD (2017). Optimization and characterization of the formation of oil-in-water diazinon nanoemulsions: Modeling and influence of the oil phase, surfactant and sonication, Journal of Environmental Science and Health, Part B:1-16.

Balaure, PC; Gudovan, D and Gudovan, I. (2017). Nanopesticides: A new paradigm in crop protection. New Pesticides and Soil Sensors:129.

Bilia, AR; Guccione, C; Isacchi, B; Righeschi, C; Firenzuoli, F and Bergonzi, MC. (2014). Essential oils loaded in nanosystems: a developing strategy for a successful therapeutic approach. Evidence-based complementary and alternative medicine : eCAM 2014:651593 doi:10.1155/2014/651593.

Bonilla, J; Atarés, L; Vargas, M and Chiralt, A. (2012). Effect of essential oils and homogenization conditions on properties of chitosan-based films, Food hydrocolloids 26(1):9-16.

Buranasuksombat, U; Kwon, YJ; Turner, $\mathrm{M}$ and Bhandari, B. (2011). Influence of emulsion droplet size on antimicrobial properties, Food Science and Biotechnology 20(3):793-800.

Chung, YS; Goeser, NJ; Cai, X and Jansky, S. (2013). The effect of long term storage on bacterial soft rot resistance in potato. American journal of potato research 90(4):351-356.

Cowan, ST and Steel, KJ. (2004). Cowan and Steel's manual for the identification of medical bacteria. Cambridge university press.

Duncan, D. (1955). Multiple ranges and multiple F test. Biometrics. 11:1-42.

El-Mohamedy, R; El-Gamal, NG and Bakeer, ART. (2015). Application of chitosan and essential oils as alternatives fungicides to control green and blue moulds of citrus fruits, Int J Curr Microbiol Appl Sci 4:629-643.

EUCAST, (2000). Determination of minimum inhibitory concentrations (MICs) of antibacterial agents by agar dilution. EUCAST Definitive Document E. Def 3.1. Clinical Microbiology and Infection 6:509-15.

Friedman, M; Henika, PR; Levin, CE and Mandrell, RE. (2004). Antibacterial activities of plant essential oils and their components against Escherichia coli O157: H7 and Salmonella enterica in apple juice, Journal of agricultural and food chemistry 52(19):6042-6048

Fry, S. (1982). Isodityrosine, a new cross-linking amino acid from plant cell-wall glycoprotein. Biochemical Journal, 204(2):449-455.

Gandía-Herrero, F; Escribano, J and García-Carmona,F. (2005). Characterization of the monophenolase activity of tyrosinase on betaxanthins: the tyraminebetaxanthin/dopamine-betaxanthin pair, Planta 222(2):307-318.

Garrity, GM; Brenner, DJ; Krieg, NR and Staley, JT, (2005), Bergey's Manual of Systematic Bacteriology. Volume 2: The Proteobacteria, vol 2. Library of Congress, USA.

Ghosh, V; Mukherjee, A and Chandrasekaran, N. (2013). Ultrasonic emulsification of food-grade nanoemulsion formulation and evaluation of its bactericidal activity. Ultrasonics sonochemistry 20(1):338-344.
Ghosh, V; Mukherjee, A, and Chandrasekaran, N. (2014). Eugenol-loaded antimicrobial nanoemulsion preserves fruit juice against, microbial spoilage. Colloids and Surfaces B: Biointerfaces 114:392-397.

Guerra,-Rosas, M; Morales-Castro, J; Cubero-Márquez, M; Salvia-Trujillo, L and Martín-Belloso, O. (2017) Antimicrobial activity of nanoemulsions containing essential oils and high methoxyl pectin during long-term storage. Food Control 77:131-138.

Hajhamed, A; Sayed, W; Yazied, A and Ghaffar, N. (2007). Suppression of bacterial soft rot disease of potato. Egypt Journal Phytopathology 35(2):69-80.

Hamed, R; Basil, M; AlBaraghthi, T; Sunoqrot, S and Tarawneh, O. (2016). Nanoemulsion-based gel formulation of diclofenac diethylamine: design, optimization, rheological behavior and in vitro diffusion studies. Pharmaceutical development and technology, 21(8):980-989.

Hammerschmidt, R; Nuckles, E and Kuć, J. (1982). Association of enhanced peroxidase activity with induced systemic resistance of cucumber to Colletotrichum lagenarium. Physiological Plant Pathology, 20(1):73-82,

Hamouda, T and Baker, J. (2000). Antimicrobial mechanism of action of surfactant lipid preparations in enteric Gramnegative bacilli. Journal of applied microbiology, 89(3):397-403.

He, L. (1983). Characteristics of strains of Pseudomonas solanacearum from China. Plant Dis 67:1357-1361.

Hollis, J and Goss, R. (1950). Factors influencing invasion of Potato by Erwinia carotovora, Phytopathology 40(9).

Honary, S and Zahir, F. (2013). Effect of zeta potential on the properties of nano-drug delivery systems-a review (Part 1). Tropical Journal of Pharmaceutical Research, 12(2):255-264

Kabeil, S; Lashin, S; El-Masry, M; El-Saadani, M; AbdElgawad M and Aboul-Einean, A. (2008). Potato brown rot disease in Egypt: current status and prospects. Am Eurasian J Agric Environ Sci, 4:44-54.

Kadhim, DH and Abbas, HA. (2015). Formulation and characterization of carvedilol nanoemulsion oral liquid dosage form. International Journal of Pharmacy and Pharmaceutical Sciences, 7(12):209-216.

Kah, M. (2015). Nanopesticides and nanofertilizers: Emerging contaminants or opportunities for risk mitigation. Frontiers in Chemistry, 3:64.

Klement, Z; Rudolph, K and Sands, D. (1990). Methods in phytopathology. Akademiai Kiado,153-180.

Lambert, R; Skandamis, PN; Coote, PJ and Nychas, GJ. (2001). A study of the minimum inhibitory concentration and mode of action of oregano essential oil, thymol and carvacrol. Journal of applied microbiology, 91(3):453462.

Leonard, S; Hommais, F; Nasser, W and Reverchon, S. (2017). Plant-phytopathogen interactions: bacterial responses to environmental and plant stimuli. Environmental microbiology, 19(5):1689-1716.

Li, J; Chang, JW, Saenger M and Deering A. (2017). Thymol nanoemulsions formed via spontaneous emulsification: Physical and antimicrobial properties. Food chemistry 232:191-197

Li, P-H and Chiang, B-H. (2012). Process optimization and stability of D-limonene-in-water nanoemulsions prepared by ultrasonic emulsification using response surface methodology. Ultrasonics sonochemistry, 19(1):192-197.

Li P-H and Lu, W-C. (2016). Effects of storage conditions on the physical stability of d-limonene nanoemulsion. Food Hydrocolloids, 53:218-224.

Liu, C-H and $\mathrm{Wu}, \mathrm{C}-\mathrm{T}$. (2010). Optimization of nanostructured lipid carriers for lutein delivery. Colloids and Surfaces A: Physicochemical and Engineering Aspects, 353(23):149-156.

Liu, H; Zhang, S; Schell, MA and Denny, TP. (2005). Pyramiding unmarked deletions in Ralstonia solanacearum shows that secreted proteins in addition to plant cell-wall-degrading enzymes contribute to virulence. Molecular plant-microbe interactions, 18(12):1296-1305 
Lyon, G. (1989.) The biochemical basis of resistance of potatoes to soft rot Erwinia spp.-a review. Plant Pathology, 38(3):313-339.

Lyon, G and McGill, FM. (1989). Inhibition of polygalacturonase and polygalacturonic acid lyase from Erwinia carotovora subsp. carotovora by phenolics in vitro. Potato research, 32(3):267-274.

Ma, Q; Davidson, PM and Zhong, Q (2016). Nanoemulsions of thymol and eugenol co-emulsified by lauric arginate and lecithin. Food chemistry, 206:167-173.

Madhuri, S; Choudhary, A and Rohit, K. (2010). Nanotechnology in agricultural diseases and food safety. Journal of Phytology, 2(4):78-82.

Mansfield, J; Genin, S; Magori, S; Citovsky, V; Sriariyanum, M; Ronald, P; Dow, M; Verdier, V; Beer, SV and Machado, MA. (2012). Top 10 plant pathogenic bacteria in molecular plant pathology. Molecular plant pathology, 13(6):614-629.

Marei, GIK; Rabea, EI and Badawy ME (2018) Preparation and Characterizations of Chitosan/Citral Nanoemulsions and their Antimicrobial Activity. Applied Food Biotechnology, 5(2):69-78.

Mayer, A; Harel, E and Ben-Shaul, R. (1966). Assay of catechol oxidase-a critical comparison of methods. Phytochemistry, 5(4):783-789.

McClements, DJ. (2015). Food emulsions: principles, practices, and techniques. CRC press.

Mishra, PR; Al Shaal, L; Müller, RH and Keck, CM. (2009). Production and characterization of Hesperetin nanosuspensions for dermal delivery. International journal of pharmaceutics, 371(1-2): 182-189.

Montesano, M; Brader, G; Ponce De León, I and Palva, ET (2005). Multiple defence signals induced by Erwinia carotovora ssp. carotovora elicitors in potato. Molecular plant pathology, 6(5):541-549.

Ngadze, E; Icishahayo, D; Coutinho, TA and Van der Waals, JE. (2012). Role of polyphenol oxidase, peroxidase, phenylalanine ammonia lyase, chlorogenic acid, and total soluble phenols in resistance of potatoes to soft rot. Plant Disease, 96(2):186-192.

Pal, R. (2011). Rheology of simple and multiple emulsions. Current Opinion in Colloid \& Interface Science, 16(1):41-60.

Pérombelon, M. (2002). Potato diseases caused by soft rot erwinias: an overview of pathogenesis. Plant pathology, 51(1):1-12.

Persson, KH; Blute, IA; Mira, IC and Gustafsson, J. (2014). Creation of well-defined particle stabilized oil-in-water nanoemulsions. Colloids and Surfaces A: Physicochemical and Engineering Aspects, 459:48-57.

Qian, C and McClements, DJ. (2011). Formation of nanoemulsions stabilized by model food-grade emulsifiers using high-pressure homogenization: factors affecting particle size. Food Hydrocolloids, 25(5):10001008 .
Sadurní, N; Solans, C; Azemar, N and García-Celma, MJ. (2005). Studies on the formation of $\mathrm{O} / \mathrm{W}$ nanoemulsions, by low-energy emulsification methods, suitable for pharmaceutical applications. European Journal of Pharmaceutical Sciences, 26(5):438-445.

São Pedro, A; Santo, I; Silva, C; Detoni, C and Albuquerque, E. (2013). The use of nanotechnology as an approach for essential oil-based formulations with antimicrobial activity. Science, Technology and Education (MéndezVilas, A, ed) 2:1364-1374 doi:1364-1374.

Sekhon, BS. (2014). Nanotechnology in agri-food production: an overview. Nanotechnology, science and applications, $7: 31$.

Shakeel, F; Baboota, S; Ahuja A; Ali, J; Aqil, M and Shafiq, S. (2007). Nanoemulsions as vehicles for transdermal delivery of aceclofenac. AAPS PharmSciTech, 8(4):191-199.

Stachurski, J and Michalek, M. (1996). The effect of the potential on the stability of a non-polar oil-in-water emulsion. Journal of colloid and interface science 184(2):433-436

Tadros, T, Izquierdo, P, Esquena, J and Solans C. (2004) Formation and stability of nano-emulsions. Advances in colloid and interface science 108:303-318.

Vance, C, Kirk, T and Sherwood, R. (1980). Lignification as a mechanism of disease resistance. Annual review of phytopathology 18(1):259-288

Verma, C; Tiwari, AKMand Mishra, S. (2017). Biochemical and Molecular Characterization of Cell Wall Degrading Enzyme, Pectin Methylesterase Versus Banana Ripening: An Overview. Asian Journal of Biotechnology 9(1):1-23

Weber, J; Olsen, O; Wegener, C; Von Wettstein, D. (1996). Digalacturonates from pectin degradation induce tissue responses against potato soft rot. Physiological and Molecular Plant Pathology 48(6):389-401.

Zachariah, T and Leela, N. (2006). Volatiles from herbs and spices. Handbook of herbs and spices 1st ed Cambridge, UK: Woodhead Publishing p:177-218 doi:pii/B9781845690175500117

Zahi, MR; Liang, $\mathrm{H}$ and Yuan, Q. (2015). Improving the antimicrobial activity of D-limonene using a novel organogel-based nanoemulsion. Food Control 50:554559

Zhang, Z; Vriesekoop, F; Yuan, Q and Liang, H. (2014). Effects of nisin on the antimicrobial activity of D-limonene and its nanoemulsion. Food chemistry 150:307-312 .

Zieslin, N and Ben Zaken, R. (1993). Peroxidase activity and presence of phenolic substances in peduncles of rose flowers. Plant Physiology and Biochemistry (France)

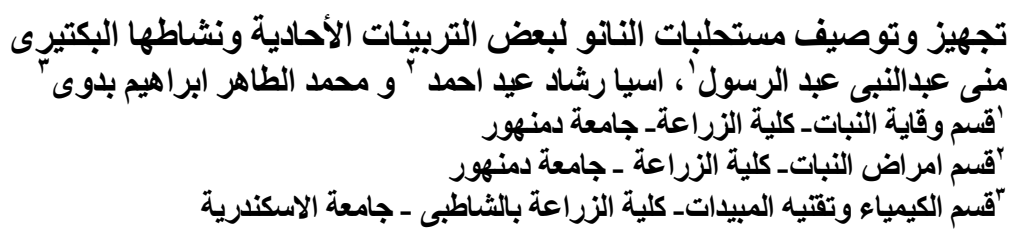

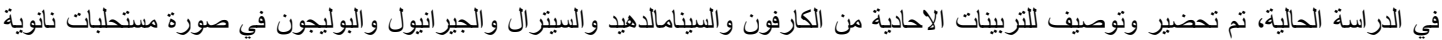

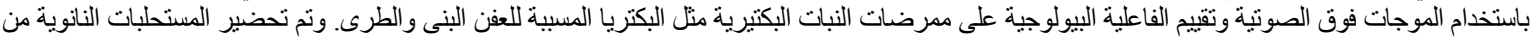

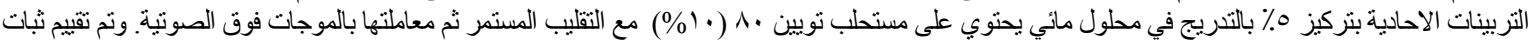

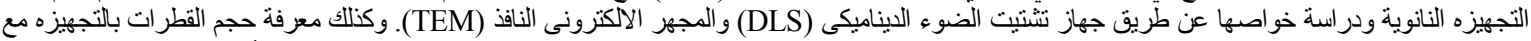

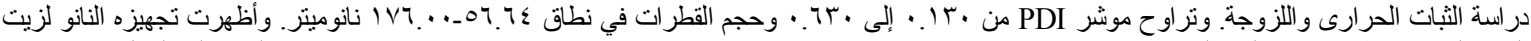

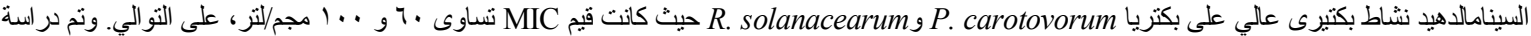

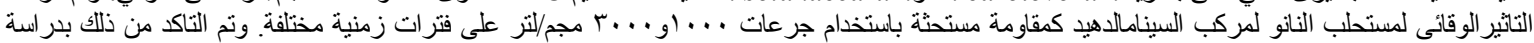

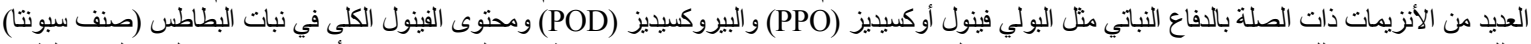

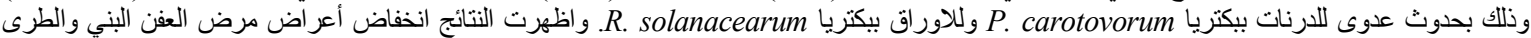

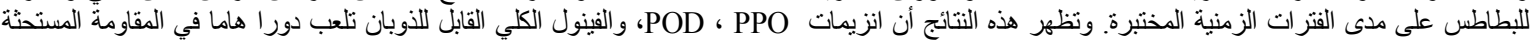

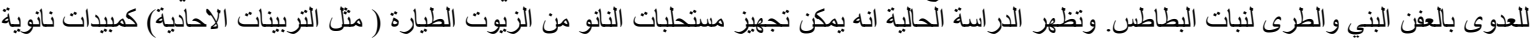
خضر اء عالية الفاعلية ضد البكتريا النباتية الممرضة كمبيدات القل تكلفة وامنة وصديقة للبيئة. 